\title{
Special issue: human remains and commemoration
}

\author{
Editorial
}

On the occasion of the first international centenary commemorations of a genocide, that of the Armenians, the cadavers without graves are reappearing and circulating openly in the written press. ${ }^{1}$ They populate the lives and imagination of those who bore witness, whose descendants today, wherever possible, transmit their memory and are publicly called to speak in their name one hundred years on. ${ }^{2}$ The circumstantial media presence of these dead bodies in the construction of accounts, and in the testimonial representation of the horror, add to the more common and recurrent presence of human bones, skulls and skeletons often seen in the photographs typically produced when it comes to commemorating victims of mass crimes. This 'on paper' presence of human remains, in all their states, is facilitated by the parallel breadth and visibility of Genocide and Memory Studies, with numerous experts regularly speaking outside of the academic field in light of current affairs. All of this marks a transmission of memories and knowledge, developed more through the images of human remains than through the monuments (when they exist) that commemorate or contain them.

However, these remains, both present and represented, are subject to a double paradox. On the one hand, their media circulation affords them a certain immateriality, meaning that their in situ presence in the scene of the crimes, in sometimes very close territories and often unexpectedly large numbers, tends to be forgotten or distanced. Yet the remains of the victims of mass violence have a material presence in space, which varies in its apparentness and in how well it is known and assumed, even long after the events. On the other hand, the expansion of Genocide and Memory Studies does not take into account the long absence of these very remains in the social sciences in general, nor in the flourishing research on commemorative practices and memorial policies in particular. Although human remains are present in images, at the heart of accounts, and in territories (even when they are abandoned, inaccessible, invisible or subject to new political violence $)^{3}$, they are seldom engaged as a research subject in themselves. This is even the case when they are mobilised in a commemorative context, within a permanent negotiation between individual/collective memories, official/unofficial rites and institutional/societal frameworks. 
Beyond the recent and innovative studies on what human remains can tell us, and how we can make them speak, we are left with one question: when we commemorate the victims, what do we do with their remains? This enquiry is far from rhetorical. It refers paradigmatically to their diverse public uses and their patrimonialisation, as already pursued by studies on history and memory in which interest is thriving. The function of human remains in commemorative practices is multiple, be it memorial, cognitive, probative or cathartic. However, their political function, with its various aspects and frameworks, is also heavily present in the articles that follow.

The question at the heart of this special issue contributes to the image-disappearance dialectic explored by Anouche Kunth in relation to the Armenian genocide, to this day denied by the Turkish State: what remains after the political erasing of the criminal act and its victims? How do we show, prove, remember or commemorate, through photography, not only the crime via the cadavers and human remains that it produces en masse, but also its denial and negation? How do we provide a 'clear representation of destruction' in the face of the political lie? How do we 'metabolise the void' into collective landmarks with the aim of tackling 'the question of afterwards?' Helen Jarvis also reflects on the iconographic representations of the horror. She questions the controversial commemorative treatments of the remains of the victims of the Khmer Rouge regime forty years on. She shows how far these 'powerful remains' (in both the material sense of bones and ashes, and the symbolic one of artistic representations) are 'hauntingly ever-present', 'well beyond memorial sites and graves'. Zahira Araguete, for her part, takes us to the very heart of collective re-inhumations and local commemorative rites, observing the spontaneous civil practices that arise in answer to the State's inaction faced with the remains of the victims of Francoism. Thus, a new space of resistance is opened up in response to the Spanish State's resignation. She visits this space using the example of the Extremadura region, where 'such novel funerary celebrations and inscriptions' from the ground acquire a specific function: the social reintegration of the Republicans who died, 'especially when a DNA match cannot be attained'. Finally, Rémi Korman and Jean-Marc Dreyfus also study the eminently political function of the commemorative treatment of human remains. The former reviews how the place given to these remains has evolved from 1994 to 2014 in the official national ceremonies commemorating the genocide of the Tutsis in Rwanda. He emphasises the change in paradigm, moving from a 'hyper-materiality' of mobilised bodies (conservation and over-exposure of bones) to a symbolising of the dead (accompanied by a new commemoration of absent or disappeared remains): a change in favour of 'the euphemisation of memorial practices' and the politics of reconciliation. Jean-Marc Dreyfus analyses the transfer of ashes from the sites of death in post-Holocaust Europe back to the victims' native countries and to Israel, from 1945 to 1960 . This important but disparate phenomenon of transporting ashes for commemorative purposes is little present in the historiography and seems to embody a specific form of 'politics of the dead' in response to a particular post-war need.

The presence, like the absence, of the remains of victims of mass crime, in all 


\section{Editorial}

forms and all commemorative contexts (centralised or decentralised, solemn or clandestine), involves fundamental stakes that transcend time. These inevitably require us to confront the question of the place and role of human remains in the community of the living in the aftermath of extreme violence. The contributions in this issue invite us to carry out this vital confrontation, which provides many new avenues for reflection.

Sévane Garibian

Guest Editor

Universities of Geneva and Neuchâtel

May 2015

\section{Notes}

1 See for example the extracts of accounts published on the Francetv info website on 24 April 2015, the date commemorating the victims of Armenian genocide. URL: http://www.francetvinfo.fr/monde/armenie/genocide-armenien/genocidearmenien-son-education-a-consiste-a-jouer-parmi-les-cadavres_871383.html (accessed 8 June 2015).

2 Echoing the above note see URL: http://www.francetvinfo.fr/monde/armenie/ genocide-armenien/appel-a-temoignages-si-votre-famille-a-connu-le-genocidearmenien-racontez-nous-son-histoire_866051.html (accessed 8 June 2015). See also URL: https://100lives.com/en/stories (accessed 23 August 2015).

3 One such example is the small collection of remains displayed in the Deir ez-Zor Armenian Memorial in eastern Syria, destroyed by the Islamic State (ISIS) in September 2014. A major pilgrimage site since its inauguration in 1990 (Deirez-Zor was the final destination for the plan to exterminate the Armenians of the Ottoman Empire), this complex featured a church, a museum and a monument. 